Moseley, F. 1968. Joints and other structures in the Silurian rocks of the Southern Shap Fells, Westmorland. Geol. J. 6, 79-96.

Phillips, W. J. 1964. The structures in the Jurassic and Cretaceous rocks on the Dorset Coast between White Nothe and Mupe Bay. Proc. Geol. Ass. 75, 373-405.

Division of Geology

J. D. WEAVER

\author{
Derby College of Art and Technology \\ Kedleston Road \\ Derby DE3 1GB \\ 17th October 1974
}

\title{
Discussion of the function of extrathecal structures in graptoloids
}

SIR,-In their discussion of the function of the proximal structures developed in certain Llandovery graptoloids, Rickards \& Koren (Geol. Mag. 111 (3), 1974, pp. 193-204) seem to present two alternative interpretations involving mode of life. Since this is a subject with which I have been concerned for a number of years I would like to discuss the arguments leading to these interpretations.

In the flattened specimens of Orthograptus obuti figured and described by Rickards \& Koren, the proximal end of the rhabdosome lies between two layers of a black semicircular membrane. Rickards and Koren consider that the latter must have been secreted by extrathecal tissue, and conclude that 'the soft tissue was probably much more extensive than the skeletal hard parts'. The authors similarly regard the virgellar meshwork and long thecal spines of Orthograptus insectiformis as suggesting 'extensive amounts of extrathecal tissue surrounding the rhabdosome'.

They argue that 'the question of function then becomes one of querying the purpose of extensive quantities of extrathecal tissue' and that 'since Bulman (1957) has suggested that the extrathecal tissue may have been vacuolated tissue (i.e. containing quantities of gas as tiny bubbles), the membranous envelope in $O$. obut $i$ and the spinose bundle of Glyptograptus tabukensis could have held vacuolated extrathecal tissue which would, probably, have floated the rhabdosomes "upside-down"'.

However, they recognize that the planar element in the observed structures, the dorsoventral orientation of the membrane in $O$. obuti, and the extension of the spinose bundles in G. tabukensis in a plane at right angles to this, suggests that the function was 'one of stability in the currents; flotation may have been achieved in what is the more likely method in most graptolites, namely by concentration of vacuolated tissue along the nema or any developments thereof'. (In spite, presumably, of those quantities of vacuolated extrathecal tissue imagined within the membranous envelope of $O$. obuti and spinose bundle of $G$. tabukensis.)

In both of these conflicting interpretations, Rickards \& Koren seem to imply passive flotation of rhabdosomes buoyed up by vacuolated tissue 'probably much more extensive than the skeletal hard parts'. I have pointed out previously $(1969,1972 a)$ that a graptolite colony carried in passive suspension within an ocean current would have rapidly exhausted the food immediately surrounding it, and that the co-ordinated ciliary currents necessary to bring in sufficient food from further away would have resulted in reciprocal movement of the rhabdosome and the evolution of automobility. Ciliary currents causing upward movement during active feeding balanced by gravitational sinking when relatively inactive would have maintained the colony at the optimum overall level in the sea. Such diurnal movement seems to be almost universal among planktonic organisms, it would be strange indeed if it had not been shared by the graptoloids.

Geol. Mag. 112 (3), 1975, pp. 322-324. Printed in Great Britain 
Again, some adjustment of density seems to be a common phenomenon in the plankton, reducing the expenditure of energy necessary to remain at the optimum level. However, it never seems to be perfect, but is always supplemented by some form of automobility which results in vertical movements relative to the surrounding water.

It is, of course, impossible to determine whether such approximate density adjustment in the graptoloids was by means of tiny gas bubbles within the tissues. However, there seems no reason to suppose that such bubbles would have been restricted to the extrathecal tissue, and there seems even less reason to suppose that the delicate spines, meshworks and membranes described in the paper under discussion carried 'extensive quantities of extrathecal tissue'. The extraordinary symmetry and adjusted gradient seen in the colonial skeletal structures seems to have been the feature of graptoloid morphology which so impressed and inspired Professor Bulman, and it was his comments upon this feature which in turn led to my notion of automobility. What could have been the purpose of such skeletal perfection if it had been enveloped in extensive masses of bubbly tissue and only passively suspended in the sea?

In my view (Kirk, 1972b) the extrathecal tissue may have been very thin, scarcely altering the profile of the skeletal structures. However the extrathecal tube or fold in which a spine or vane was secreted would have necessarily had a greater surface area, and perhaps a somewhat greater volume. Consequently, if the secreted structure had been delicate, vacuolation of its extrathecal envelope could have given the mantled structure a net buoyancy. On the other hand a more massive structure like the vaned virgula of some biserial forms, even within a vacuolated mantle, could have acted as a weight. This idea, is, of course, unverifiable, but the precision of form and arrangement of spines and vanes in the graptoloids supports the hypothesis that they were only thinly mantled and that their hydrodynamic effect usually depended primarily on their form and arrangement, and only secondarily on their net density.

I have suggested (Kirk, 1969, 1972 b, 6-19) that the morphological evolution of the graptoloids has been primarily controlled by the need to adjust hydrodynamically, one way or another, to the feeding currents. The details of this hypothesis, and the arguments leading to the conclusion that all graptoloids lived in mobile suspension with the sicula opening upwards, are too numerous to recapitulate here but can be found in the papers listed below.

I propose now to examine the structures described by Rickards and Koren in the light of this hypothesis.

In $O$. obuti, we are told that the virgellar network was formed early, and that its membrane only became sclerotized late in the life of the colony. This suggests that it could hardly have functioned as a weight keeping the proximal end down and the rhabdosome the orthodox 'right way-up'. Thinly mantled with possibly vacuolated extrathecal tissue, such a delicate structure could well have been slightly buoyant, expecially in the young stages of growth when relatively few mature zooids would have had to support a relatively large proportion of immature passengers. On this hypothesis the virgellar structure could have 'helped' to support the rhabdosome with the sicular aperture uppermost as is required by the theory of automobility.

We are told also that in flattened specimens of $O$. obuti the virgellar membrane is seen to be two layered, but that it could be interpreted either as two vanes - one above and one below the rhabdosome, or as a single membranous structure enveloping the proximal region.

Whether consisting of two vanes or of an originally flattened hood, the structure would have had, as Rickards and Koren suggest, a stabilizing effect, not however in 'the currents' which carry the plankton bodily from one part of the ocean to another, and in which they would have been ineffective, but in those feeding currents which moved relative to the rhabdosome. The vertical laciniae of Glossograptus holmi and Paraglossograptus, secreted within folds of extrathecal tissue, may have had a similar effect (Kirk, $1972 a$, p. 132, 1972b, p. 11). Examination of the specimens of Nymphograptus velatus figured by Elles \& Wood (1908, Pt. VII, p. 330, PI. XXIV), and kindly lent to me by the Geological Survey of Scotland, suggests that here also the ladder-like laciniae may have been secreted within and supported delicate vanes extending from the obverse and reverse faces of the rhabdosome. (Vertical vanes separating the feeding currents of the two rows 
of thecae, seem a more likely interpretation of the laciniae than the open meshwork which (Kirk, 1972a, p. 132) I believed merely to have had a frictional significance.) In all these examples, the vertical vanes, the vertical rows of apertural processes, and the vertical rows of ventro-laterally directed lophophore branches would have combined to form a kind of box-kite over which the feeding currents would have flowed unimpeded, and which would have risen smoothly and without rotation as a consequence. (The flattening of the brush of spines in G. tabukensis may also have prevented rotation, in addition to the more usual frictional effect of such processes.)

If, however, the virgellar membrane of $O$. obuti had been a hood which only became flattened as a consequence of compression during fossilization (and this seems less probable since a hood would have impeded the flow of feeding currents to the proximal zooids), then its effect would have been less directional. However, its parachute-like form, in addition to any net buoyancy it might have had, could have retarded sinking during periods of reduced feeding activity. In $O$. insectiformis a similar proximal 'parachute', in conjunction with the long thecal spines, could again have contributed to a balanced, vertical, near immobility. A comparable effect might have been produced in Neurograptus fibratus (Elles \& Wood, 1908, Pt. VII, p. 332, fig. 218) by the horizontally extended, membrane-bearing, antler like 'scopulae'. By reducing the tendency to sink during periods of reduced activity, the feeding currents to the rhabdosome would have been enabled to decrease their downward component and to increase their general centripetal effect during periods of high activity. This would have been a distinct advantage in the case of a vertically elongated colony.

It is hoped that further information will become available about the precise nature of proximal structures, leading to a less ambiguous interpretation of their function in the automobility of the graptoloid colonies.

\section{References}

Bulman, O. M. B. 1970. Graptolithina. In R. C. Moore (Ed.): Treatise on invertebrate palaeontology, Pt. V. Geol. Soc. America and Univ. of Kansas Press, New York.

Elles, G. L. \& Wood, E. M. R. 1908. A Monograph of British Graptolites. Paleontogr. Soc. Monogr., Pt. VII, 318-33.

Jones, W. D. V. \& Rickards, R. B. 1967. Diplograptus penna Hopkinson 1869, and its bearing on vesicular structures. Palaont. Zeitschr., v. 41, 173-85.

Kirk, N. H. 1969. Some thoughts on the ecology, mode of life, and evolution of the Graptolithina. Proc. geol. Soc. No. 1659, 273-92.

Kirk, N. H. 1972(a). More thoughts on the automobility of the graptolites. Jl geol. Soc. 128, $127-33$.

Kirk, N.H. 1972(b). Some thoughts on the construction of the rhabdosome in the Graptolithina, with special reference to extrathecal tissue and its bearing on the theory of automobility. Geol. Dept. Publ. No. 1, University College of Wales, Aberystwyth.

Kirk, N. H. 1973. Some thoughts on the construction and functioning of the rhabdosome in the Retiolitidae. Geol. Dept. Publ. No. 3, University College of Wales, Aberystwyth.

Rickards, R. B. \& Koren, T. N. 1974. Virgellar meshworks and sicular spinosity in Llandovery graptoloids. Geol. Mag. 111 (3), 193-204.

Department of Geology

N. H. KIRK

University College of Wales

Aberystwyth

Wales

6th September 1974 